\title{
Paradoxical Effects of a Synthetic Metalloproteinase Inhibitor That Blocks Both P55 and P75 TNF Receptor Shedding and TNF $\alpha$ Processing in RA Synovial Membrane Cell Cultures
}

\author{
Lynn M. Williams, Deena L. Gibbons, Andrew Gearing, ${ }^{*}$ Ravinder N. Maini, Marc Feldmann, and Fionula M. Brennan \\ The Mathilda and Terence Kennedy Institute of Rheumatology, Sunley Division, Hammersmith, London W6 8LW United Kingdom; and \\ *Neures Ltd, 4-10 The Quadrant, Abingdon, Oxon, United Kingdom
}

\begin{abstract}
We have previously hypothesized that the pro-inflammatory cytokine $\mathrm{TNF} \alpha$ has a pivotal role in the pathogenesis of rheumatoid arthritis (RA). It mediates its effects by crosslinking surface p55 or p75 TNF receptors (TNF-R), which can be proteolytically cleaved to yield soluble fragments. Upon binding TNF $\alpha$ soluble TNF-R (sTNF-R) can inhibit its function. We investigated the enzymatic nature of the proteases involved in TNF-R cleavage, and found that this process is blocked by a synthetic inhibitor of matrix metalloproteinase activity (MMP), BB-2275. Inhibition of TNF-R cleavage was observed in a number of different cell types, as detected by retention of surface bound TNF receptor and by less STNF-R released into the cell supernatant. The augmentation of surface TNF-R expression was of biological relevance as TNF $\alpha$-mediated necrosis of human KYM.1D4 rhabdosarcoma cells was enhanced $\sim 15$-fold in the presence of BB-2275. The addition of BB-2275 to rheumatoid synovial membrane cell cultures totally inhibited MMP activity and also significantly reduced the levels of soluble TNF $\alpha(P<0.006)$, p55 sTNF-R $(P<0.006)$, and p75 sTNF-R $(P<0.004)$. Paradoxically, despite the reduction in soluble TNF $\alpha$ levels, the production of IL-1 $\beta$, IL-6, and IL-8, cytokines whose production was previously demonstrated to be inhibited by the addition of a neutralizing anti-TNF $\alpha$ antibody were not down-regulated by BB-2275. These results raise the interesting possibility that a close relationship exists between the enzyme(s) which process membranebound $\mathrm{TNF} \alpha$, and those involved in surface TNF-R cleavage. Furthermore our observations suggest that hydroxamate inhibitors of MMP activity which block TNF $\alpha$ secretion and TNF-R cleavage may not modulate down-stream effects of $\mathrm{TNF} \alpha$, and as such suggest that the precise specificity of these compounds will be highly relevant to their clinical efficacy in inflammatory diseases. (J. Clin. Invest. 1996. 97: 2833-2841.) Key words: rheumatoid arthritis • tumor necrosis factor $\bullet$ TNF receptor $\bullet$ matrix metalloproteinase
\end{abstract}

Address correspondence to Dr. Fionula M. Brennan, Kennedy Institute of Rheumatology, Sunley Division, 1 Lurgan Avenue, London W6 8LW, UK. Phone: 0181741 8966; FAX: 081563 0399; E-mail: f.brennan@s1.cxwms.ac.uk. D.L. Gibbons' present address is Leukaemia Research Fund Centre, Institute of Cancer Research Chester Beatty Institute, Fulham Road, London SW3.

Received for publication 6 December 1995 and accepted in revised form 12 March 1996.

J. Clin. Invest.

(C) The American Society for Clinical Investigation, Inc.

0021-9738/96/06/2833/09 \$2.00

Volume 97, Number 12, June 1996, 2833-2841

\section{Introduction}

Tumor necrosis factor- $\alpha(\mathrm{TNF} \alpha)$ is a pro-inflammatory cytokine which has a major role in the pathology of septic shock and chronic inflammatory diseases such as rheumatoid arthritis (RA). In studies of the expression and regulation of cytokines in RA, we have shown that $\mathrm{TNF} \alpha$ has a pivotal role in the cytokine cascade (reviewed in reference 1 ). Thus, using an in vitro culture model of cells isolated from the RA synovium, we observed that the spontaneous production of a number of cytokines, including IL-1 (2), GM-CSF (3), and more recently IL-6 and IL-8 (4), was decreased in the presence of neutralizing antibodies to TNF $\alpha$. TNF $\alpha$ mediates its diverse biological effects by binding to either of two high affinity receptors, of 55 and $75 \mathrm{kD}(5,6)$. Both of these receptors are upregulated on the surface of cells in RA synovial tissue compared with peripheral blood mononuclear cells (7). Furthermore, using immunohistology we have shown that CD68 positive macrophages at the cartilage-pannus junction, which is the moving edge of tissue destruction migrating from the synovium into the cartilage produce TNF $\alpha$ (8), and also express TNF receptors (TNF-R) (p55 and p75) (9), indicating that these cells may respond to $\mathrm{TNF} \alpha$ in an autocrine manner. In conjunction with upregulation of pro-inflammatory mediators, homeostatic regulating mechanisms are also in operation, including the production of functional inhibitors of TNF such as IL-10 (10) and soluble TNF receptors (sTNF-R) (11), both of which are upregulated in RA synovial joint cells $(10,12)$. sTNF-R, the truncated circulating forms of the membrane associated receptors, were first identified in urine, and demonstrated to bind and neutralize the cytotoxic activity of $\operatorname{TNF}(13,14)$ a function reversed by preincubation with neutralizing TNF-R antibodies $(11,12)$.

The mechanism of sTNF-R production is not understood, although it is thought to involve proteolytic cleavage of cell surface receptor, as there is no evidence for alternatively spliced mRNA. Site directed mutagenesis of the human p55 TNF-R (15) has indicated an Asn/Val sequence close to the transmembrane region as a putative cleavage site. Similar site directed mutagenesis studies have not been reported for the p75 TNF-R. However sequences Ala-Val 176-177, 191-192 and Val-Val-Ala 165-167 are potential cleavage sites as they are recognized by neutrophil elastase, an enzyme which induces cleavage of the p75, but not p55 TNF-R in neutrophils (16).

Cells such as macrophages, fibroblasts, and chondrocytes in rheumatoid synovial tissue produce a wide range of enzymes which contribute to the inflammatory response. High levels of matrix metalloproteinases such as collagenase and stromelysin are produced, and these enzymes are involved in the breakdown of extracellular matrix molecules (reviewed in reference 17). In this report we demonstrate that a broad-spectrum matrix metalloproteinase inhibitor, BB-2275, inhibits the release 
of both the p55 and p75 TNF-R. This inhibition is reflected in the reduction of TNF-R levels in the culture medium with a corresponding increase in cell surface TNF-R expression. Furthermore inhibition of TNF-R processing is independent of the inhibitory effect of BB-2275 on processing of the TNF $(26 \mathrm{kD})$ precursor, and matrix metalloproteinases can cleave pro-TNF $\alpha$ in vitro (18). Our observations suggest that a matrix metalloproteinase-like enzyme(s) is also involved in conversion of the membrane associated TNF-Rs to soluble, circulating molecules.

\section{Methods}

Isolation of peripheral blood monocytes. Single donor plateletpheresis residues were purchased from the North London Blood Transfusion service (Colindale, UK). Mononuclear cells were isolated by Ficoll/ Hypaque centrifugation (specific density $1.077 \mathrm{~g} / \mathrm{ml}$ ) before monocyte separation in a Beckman JE6 elutriator. Elutriation buffer consisted of RPMI 1640 (Biowit, Paisley, Scotland) supplemented with 1\% FCS (vol/vol)(GIBCO). Monocyte purity was estimated by flow cytometry using directly conjugated anti-CD45 and anti-CD14 antibodies (Leucogate, Becton Dickinson, UK) and was routinely greater than $90 \%$. All media used in the separation and culture of monocytes were tested for endotoxin using the Limulus Amoebocyte Lysate test (BioWhittaker Inc., Walkersville, MD), and were rejected if the endotoxin concentration exceeded $0.1 \mathrm{U} / \mathrm{ml}$.

Generation of $T$ cell lines. $\mathrm{T}$ cell lines were generated from mononuclear cell populations by stimulation with $1 \mu \mathrm{g} / \mathrm{ml}$ PHA (Difco, Detroit, IL) and 10ng/ml IL-2 (Hoffman La Roche, Nutley, NJ) as described previously (19). Cells were propagated with fresh medium every 4 days until day $12-14$, when cells were harvested and restimulated with PHA for $24 \mathrm{~h}$ before use in experiments.

Dissociation of synovial tissue. Synovial membrane tissue was obtained aseptically from the joints of RA patients, dissected from the surrounding tissues, and digested in vitro with collagenase type IV (Sigma Chemical Co., St. Louis, MO) and DNAse type I (Sigma Chemical Co.), as previously described (2).

Cell culture conditions. HeLa (epithelial carcinoma), JiJoye (Burkitt lymphoma) U937 (monocytic leukaemia) (all obtained from ATCC), elutriated monocytes, T cell lines, and dissociated RA synovial membrane cells were cultured at $1-2 \times 10^{6} / \mathrm{ml}$ in 48 well culture plates (Falcon, Becton Dickinson, Lincoln Park, NJ, USA) for varying time periods in RPMI 1640, containing 5\% heat inactivated FCS (Advanced Protein Products, Brierley Hill, England, UK), $2 \mathrm{mM}$ L-glutamine and antibiotics. At the start of the culture period, cells were left either unstimulated, or stimulated with one or other of the following:

IL-10 (10-100 U/ml, a gift from Dr. K. Moore DNAX, Palo Alto), LPS (10 ng/ml E. Coli derived, Sigma), or PMA (10 ng/ml, Sigma Chemical Co.) in the presence or absence of the metalloproteinase inhibitor BB-2275 (0-100 $\mu \mathrm{M}$, British Biotech Pharmaceuticals Ltd, $\mathrm{UK})$. In some experiments the neutralizing chimeric anti TNF $\alpha$ antibody cA2, a gift from Dr. J. Ghrayeb (Centocor, Malvern, PA) was included. Cell supernatants were harvested at varying times, and stored at $-80^{\circ} \mathrm{C}$ before assessment for cytokine levels.

Monoclonal antibodies and fluorescence analysis. Monoclonal antip55 TNF-R antibody, H398 was kindly provided by Dr. K. Pfizenmaier (Universitat Stuttgart, Stuttgart, Germany), monoclonal anti-p75 TNF-R antibody, UTR-1, and monoclonal anti-p55 TNF-R antibody Htr-9 were kindly provided by Dr. M. Brockhaus (Roche, Basel, Switzerland) and monoclonal anti-p55 TNF-R antibody TBP II was kindly provided by Dr. G. Adolf (Ernst Boehringer Institut, Vienna, Austria). OX14 (mouse anti-rat $\mathrm{IgG}_{1}$ ) and $\mathrm{OX} 12$ (mouse anti rat $\mathrm{IgG}_{2 \mathrm{a}}$ ) served as control monoclonal antibodies and were provided by Dr. D. Mason (Oxford, UK). Cells to be immunostained for surface TNF-R expression were harvested, pelleted and resuspended in an ice cold buffer containing $10 \mathrm{mM}$ sodium citrate and, $0.14 \mathrm{M}$ sodium chloride, $\mathrm{pH} 4$, for $1 \mathrm{~min}$ to remove TNF bound to receptor (19) and then washed again in ice cold "wash buffer" containing $2 \%$ FCS and $0.02 \%$ sodium azide in PBS. Cells were resuspended at $5 \times 10^{5}$ cells per polystyrene round bottomed tube (Falcon) incubated for $30 \mathrm{~min}$ at $4^{\circ} \mathrm{C}$ with the appropriate anti-TNF-R antibody or control monoclonal antibody, washed twice with "wash buffer" and then incubated with a 1:100 dilution of goat anti-mouse IgG-biotin, washed again and then incubated with a 1:100 dilution of streptavidin-phycoerythrin (Southern Biotechnology Associates, Birmingham, AL). Cells were washed three times further, fixed with $1 \%$ formaldehyde for 10 min and viable cells analyzed for TNF-R expression by FACS ${ }^{\circledR}$ analysis by linear FL2 acquisition. Results were calculated as mean FL2 units (H398 or UTR-1) after subtraction of the background staining (OX14 or OX12).

Ligand binding assay. A competitive ligand binding assay using cold competitive TNF $\alpha$ and ${ }^{125}$ I-labeled TNF $\alpha$ (19) was used to determine surface TNF-R expression on the KYM.1D4 rhabdomyosarcoma cells due to the small number of TNF-R molecules expressed. Briefly, triplicate samples of the cells in suspension were incubated with either $40 \mathrm{nM}$ TNF $\alpha$ or $2 \%$ FCS/PBS for $1 \mathrm{~h}$ on ice. ${ }^{125}$ I-labeled $\mathrm{TNF} \alpha(4 \mathrm{nM})$ was added and the mixture incubated for $3 \mathrm{~h}$ at $4^{\circ} \mathrm{C}$. Samples were layered onto 5-20\% sucrose gradients, spun $(14,000 \mathrm{~g}$, $8 \mathrm{~min}$ ), frozen in dry ice and the tip containing the cell pellet removed and counted. The TNF $\alpha$ binding to cell receptors was determined by subtracting nonspecific ${ }^{125} \mathrm{I}$-labeled TNF $\alpha$ binding in the presence of excess cold TNF $\alpha(40 \mathrm{nM})$.

Soluble TNF-R assay. sTNF-R were assayed in the cell supernatant by ELISA, as previously described (20). In each case the monoclonal anti TNF-R (4C8 or 1H7) was used as the capture antibody and the polyclonal rabbit anti TNF-R antibody conjugated to biotin used as the detection antibody (gifts of Dr. W. Buurman, Rijks Universiteit Limburg, Maastricht, The Netherlands). Streptavidin-horseradish peroxidase conjugates were used to detect the biotinylated antibodies followed by a homogenic substrate of tetramethylbenzidine dihydrochloride (TMB; Sigma Chemical Co.). Results are expressed as the mean of triplicate samples and the limit of detection of both ELISAs was $30 \mathrm{pg} / \mathrm{ml}$.

Cytokine immunoassays. Reagents for the TNF $\alpha$ ELISA were provided by Dr. W. Buurman, Rijks Universiteit Limburg, Maastricht, The Netherlands. The ELISA performed as described previously (21), using the coat monoclonal anti TNF $\alpha$ antibody (61E71) and developed using the polyclonal rabbit anti $\mathrm{TNF} \alpha$ antibody conjugated to biotin. Streptavidin-horseradish peroxidase conjugates was used to detect the biotinylated antibody followed by a substrate of tetramethylbenzidine dihydrochloride (TMB; Sigma Chemical Co.). Results are expressed as the mean of duplicate samples. The sensitivity limit of the assay was $1.4 \mathrm{pg} / \mathrm{ml}$. Reagents for the IL-6 ELISA were a gift from Dr. F. Di Padova (Sandoz, Basel, Switzerland), and the ELISA performed using the coat anti-IL-6 mAb (LN1 314-14), and developed using the detection anti-IL-6 mAb (LN1 14-110), as previously described (4). The range of the assay was from $0.1-25 \mathrm{ng} / \mathrm{ml}$. Reagents for the IL-8 ELISA were a gift from Dr. W.L. Wong (Genentech, South San Francisco, CA), and the ELISA performed using the coat anti-IL-8 mAb (4.1.3) and detected with a biotinylated anti-IL-8 $\mathrm{mAb}$ (A5.12.14) as previously described (4). The range of the assay was from $0.12-10 \mathrm{ng} / \mathrm{ml}$. Reagents for the IL-1 $\beta$ ELISA were a gift from Drs. J. Kenney and D. Webb (Syntex, Palo Alto, CA) and the ELISA performed using the coat anti-IL-1 $\beta$ mAb (ILB1-H6) and detected with anti-IL-1 $\beta$ mAb (ILB1-H67) as previously described (4). The range of the assay was from $10 \mathrm{pg}-7.4 \mathrm{ng} / \mathrm{ml}$.

TNF bioactivity. TNF $\alpha$ cytotoxicity was measured using KYM1D4 cells, a subline of KYM (human rhabdomyosarcoma cells) (22). These cells were incubated at $2 \times 10^{5}$ cells $/ \mathrm{ml}$ in triplicate overnight or for 15 minutes in RPMI 1640 containing $0.024 \mathrm{M}$ sodium bicarbonate, $2 \mathrm{mM}$ glutamine, $100 \mathrm{U} / \mathrm{ml}$ penicillin and $100 \mu \mathrm{g} / \mathrm{ml}$ streptomycin, supplemented with 5\% FCS (Advanced Protein Products, Brierley Hill, UK) in the presence or absence of BB-2275 (0-10 $\mu$ M). KYM1D4 cells were washed three times and then resuspended in culture 
medium, centrifuged $(1,000 \mathrm{~g}, 5 \mathrm{~min})$ and then diluted to $2 \times 10^{5}$ cells/ $\mathrm{ml}$ in RPMI and 10\% FCS. $100 \mu \mathrm{l}$ of the cell suspension was added to each well of 96 flat-bottom well tissue culture plates (Falcon, Becton Dickinson, Lincoln Park, NJ) and cultured at $37^{\circ} \mathrm{C}$ for $24 \mathrm{~h}$ in the presence of huTNF $\alpha(0-1,000 \mathrm{pg} / \mathrm{ml})$ specific activity $2 \times 10^{8} \mathrm{U} / \mathrm{mg}$, a gift from Prof. W. Stec (Center of Molecular and Macromolecular Studies, Polish Academy of Science, Lodz, Poland). $10 \mu \mathrm{l}$ of MTT $(5 \mathrm{mg} / \mathrm{ml})$ was added for $8 \mathrm{~h}$, followed by $50 \mu \mathrm{l}$ of $10 \%$ SDS in $0.02 \mathrm{M}$ $\mathrm{HCl}$ for $12 \mathrm{~h}$ of incubation at $37^{\circ} \mathrm{C}$, and optical density of culture assessed at $590 \mathrm{~nm}$

Assay for matrix metalloproteinase activity. Matrix metalloproteinase (MMP) ${ }^{1}$ activity was measured in synovial cell culture supernatants using an assay based on the cleavage of a synthetic, fluorogenic peptide substrate (23). The culture supernatants and a medium-only control were incubated with the peptide substrate (7-methoxycoumarin-4-yl)Acetyl-Pro-Leu-Gly-Leu-(3-[2,4-dinitrophenyl]-L-2,3-diaminopropionyl)-Ala-Arg- $\mathrm{NH}_{2}$ (Calbiochem-Novaiochem Ltd.) at a final concentration of $6 \mu \mathrm{M}$ for $2 \mathrm{~h}$ at $37^{\circ} \mathrm{C}$. To determine the level of MMP-specific peptide cleavage, a second series of reactions were set up containing a broad spectrum MMP inhibitor, BB-2116, at a final concentration of $10 \mu \mathrm{M}$. The reactions were stopped by addition of an equal volume of $3 \%$ aqueous acetic acid. The fluorescence intensity was measured in a Fluostar fluorimeter (SLT instruments) at excitation and emission wavelengths of 320 and $405 \mathrm{~nm}$ respectively. MMP activity was determined by subtraction of the fluorescence intensity of the culture medium blank and BB-2116 control values from the sample values.

Statistics. Statistical analysis was performed using the Minitab 8.2 software for the Macintosh computer, differences between the different treatment groups which consisted of matched samples was assessed both by the Student's $t$ test (for normally distributed data) and by the nonparametric Wilcoxon signed rank (for data not normally distributed).

\section{Results}

BB-2275 inhibits shedding of TNF-R in a range of different cell types. To investigate the effect of the metalloproteinase inhibitor BB-2275 on TNF-R shedding, a range of different cells were studied which express one or both surface TNF-R. The transformed cell lines U937 (expressing p75 > p55), JiJoye (p75 + ve only), HeLa cells (p55 + ve only), normal elutriated monocytes $($ p55 + ve, p75 + ve) and T cell lines $(\mathrm{p} 75>$ p55)

1. Abbreviation used in this paper: MMP, matrix metalloproteinase.

Table I. Concentration $\left(I C_{50}\right)$ of BB-2275 to Inhibit Soluble TNF-R Production by $50 \%$

\begin{tabular}{lcc}
\hline \multicolumn{1}{c}{ Cell line } & p75 sTNF-R & p55 sTNF-R \\
\hline U937 & $0.8 \mu \mathrm{M}$ & $2.0 \mu \mathrm{M}$ \\
Jijoye & $0.8 \mu \mathrm{M}$ & Not present \\
HeLa & Not present & $0.75 \mu \mathrm{M}$ \\
Peripheral blood monocytes & $0.8 \mu \mathrm{M}$ & $0.8 \mu \mathrm{M}$ \\
T cell line & $0.45 \mu \mathrm{M}$ & Not shed significantly
\end{tabular}

Cells were cultured at $1-2 \times 10^{6} / \mathrm{ml}$ and stimulated with PMA $(10 \mathrm{ng} / \mathrm{ml})$ as described in Methods, in the presence or absence of increasing concentrations $(0-100 \mu \mathrm{M})$ of the metalloprotease inhibitor (BB-2275). Supernatants were harvested after $24 \mathrm{~h}$ and soluble p55 or p75 TNF-R levels measured by ELISA. Results are expressed as the $50 \%$ inhibitory concentration for BB-2275. were stimulated with PMA to induce sTNF-R production in the presence or absence of increasing amounts of BB-2275 (0 $100 \mu \mathrm{M})$. Supernatants were harvested after $24 \mathrm{~h}$ in culture, and p55 and/or p75 sTNF-R levels measured by ELISA. In each cell type tested, BB-2275 inhibited PMA-induced TNF receptor shedding in a dose dependent manner with the $50 \%$ inhibitory concentration $\left(\mathrm{IC}_{50}\right)$ at $0.8 \mu \mathrm{M}$ for both $\mathrm{p} 55$, and $\mathrm{p} 75$ sTNF-R (Table I). The $\mathrm{IC}_{50}$ for p55 sTNF-R release in U937 cells was slightly higher $(2 \mu \mathrm{M})$ but as only small amounts of p55 sTNF-R are expressed, or released from U937 cells, this could not be quantified accurately.

$B B-2275$ modulates surface TNF- $R$ expression. To investigate whether inhibition of TNF-R shedding by BB-2275 was reflected in retention of surface receptor expression, U937
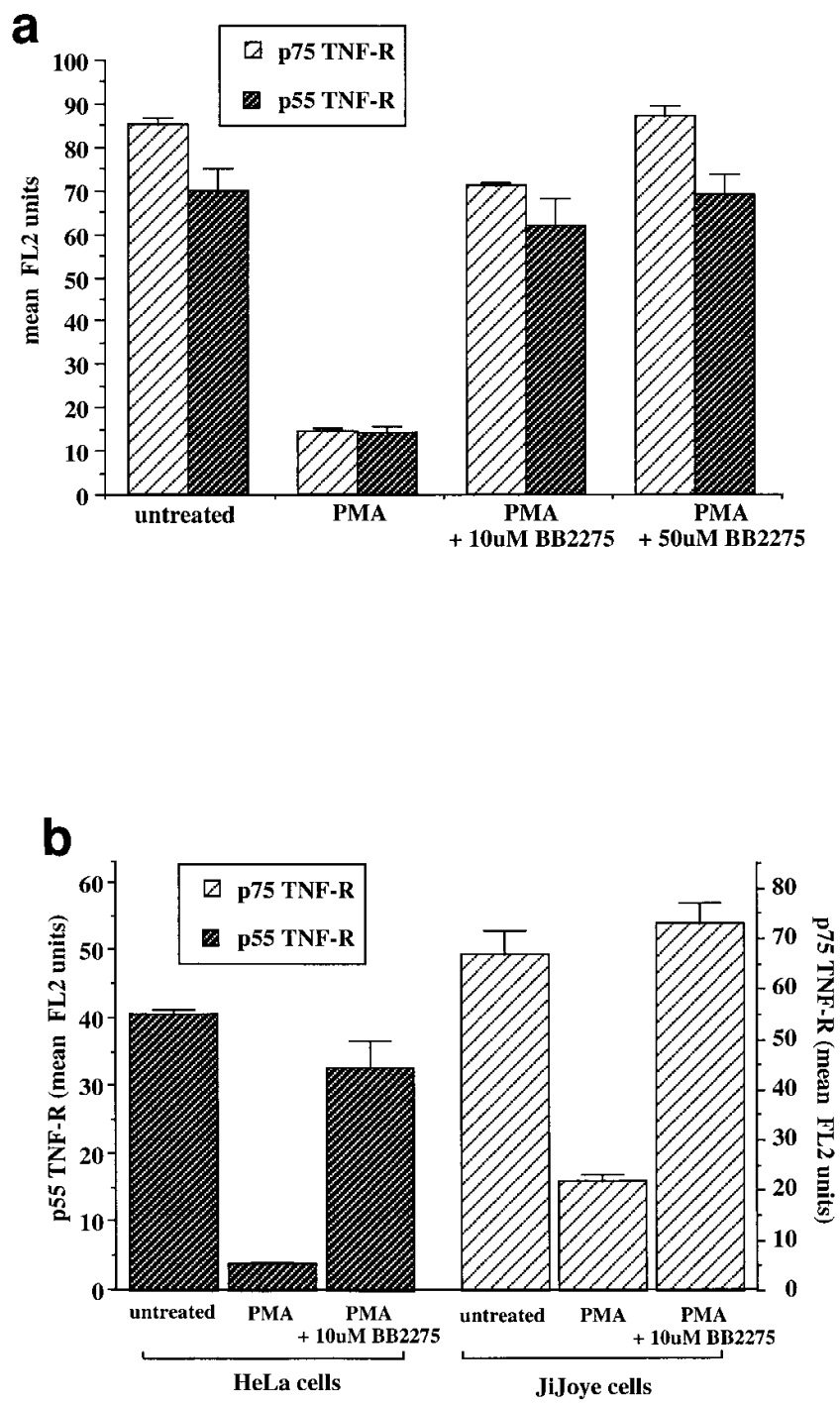

Figure 1. The effect of the metalloproteinase inhibitor BB-2275 on surface TNF-R expression. U937 cells (Fig. 1 a) Hela and JiJoye cells (b) were set up in culture in RPM1 1640 5\% FCS +/- PMA (10 ng/ $\mathrm{ml})+/-\mathrm{BB} 2275(0-50 \mu \mathrm{M})$. Cells were harvested after $2 \mathrm{~h}$ in culture and analyzed for $\mathrm{p} 55$ and/or $\mathrm{p} 75$ surface TNF-R expression with immunostaining using monoclonal anti p55 (HTR-9) and p75 (UTR-1) antibodies and analyzed by flow cytometry. Results are expressed as mean FL2 units \pm SD (triplicate culture) after linear acquisition by FACS. 
(p75 > p55), HeLa (p55 + ve) and JiJoye (p75 + only) cells were cultured for 2 hours with PMA in the presence or absence of BB-2275. Surface TNF-R expression was determined by immunostaining with monoclonal anti TNF-R antibodies and flow cytometry analysis. In each case, BB-2275 reversed the PMA-induced down regulation of surface TNF-R on U937 (Fig. $1 a$ ), HeLa and JiJoye cells (Fig. $1 b$ ). This analysis by flow cytometry was also verified separately by ligand binding analysis with ${ }^{125} \mathrm{I}$ - labeled TNF $\alpha$ (data not shown).

The effects of BB-2275 are independent of processing of $T N F$. During the course of these studies it was reported by three different groups $(18,24,25)$ that hydroxamic acid MMP inhibitors such as BB-2275 inhibit processing of membranebound $26-\mathrm{kD} \mathrm{TNF} \alpha$ to the secreted $17-\mathrm{kD}$ form. As TNF $\alpha$ itself induces down regulation of surface TNF expression and induction of TNF-R both in vitro and in vivo $(26,27)$, it was necessary to exclude the possibility that inhibition of TNF-R cleavage by BB-2275 was mediated indirectly through inhibition of TNF $\alpha$ processing. This was not of concern in the experiments performed on HeLa cells, which unlike myeloid cells do not express $\mathrm{TNF} \alpha$ protein spontaneously or after stimulation with PMA (28). In contrast, in LPS-stimulated monocyte cultures, the inclusion of a $\mathrm{F}\left(\mathrm{ab}^{\prime}\right)_{2}$ preparation of the neutralizing anti-TNF $\alpha$ antibody, cA2, had a small inhibitory effect on the production of p75 sTNF-R from $5200 \mathrm{pg} / \mathrm{ml}$ to $4000 \mathrm{pg} / \mathrm{ml}$

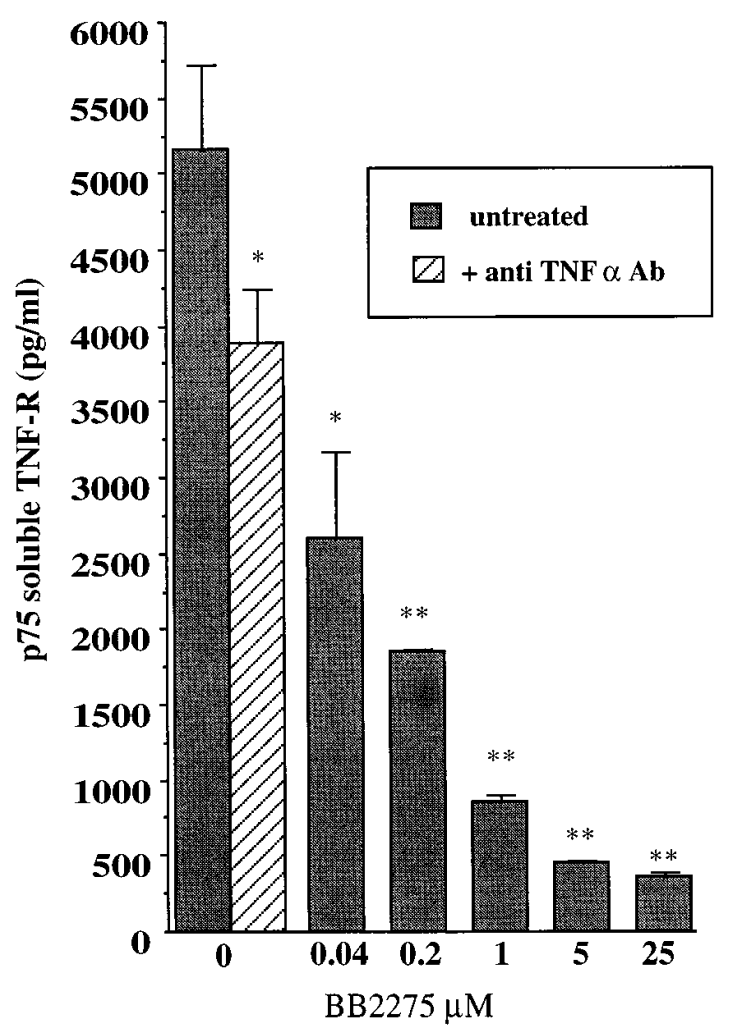

Figure 2. The metalloproteinase inhibitor BB-2275 inhibits LPS induced $\mathrm{p} 75 \mathrm{sTNF}$ production in monocytes. Monocyte cultures were set up in triplicate at $2 \times 10^{6}$ cells $/ \mathrm{ml}$ with LPS $(10 \mathrm{ng} / \mathrm{ml})+/-$ a $\mathrm{F}\left(\mathrm{ab}^{\prime}\right)_{2}$ anti $\mathrm{TNF} \alpha$ antibody $(2.5 \mu \mathrm{g} / \mathrm{ml})$ in the presence of BB2275 $(0-5 \mu \mathrm{M})$. Supernatants were harvested after $24 \mathrm{~h}$ in culture and p75 sTNF-R levels determined by ELISA. Results are expressed as mean $\pm \mathrm{SD}(\mathrm{pg} / \mathrm{ml})$ of triplicate culture $* P<0.05$, $* * P<0.01$, as determined by Student's $t$ test.

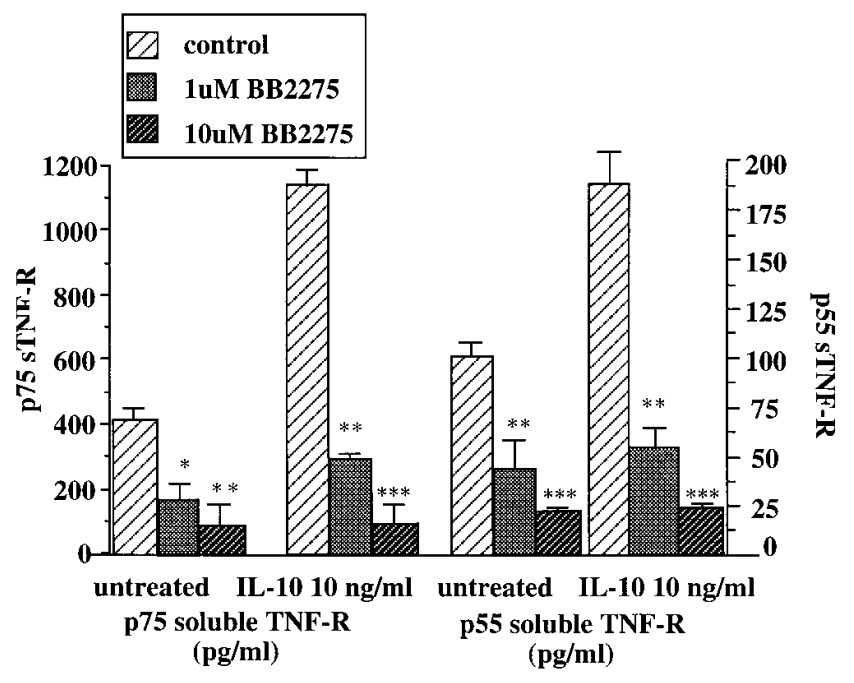

Figure 3. The metalloproteinase inhibitor BB-2275 inhibits IL-10 induced $\mathrm{p} 55$ and $\mathrm{p} 75$ sTNF-R production in monocytes. Monocyte cultures were set up in triplicate at $2 \times 10^{6} / \mathrm{ml}+/-$ IL-10 $(10 \mathrm{ng} / \mathrm{ml})$ with BB2275 $(0-10 \mu \mathrm{m})$. Supernatants were harvested after $24 \mathrm{~h}$ in culture and $\mathrm{p} 55$ and p75 sTNF-R levels determined by ELISA. Results are expressed as mean $\pm \mathrm{SD}(\mathrm{pg} / \mathrm{ml})$ of triplicate culture. $* P<0.05$, $* * P<$ $0.01, * * * P<0.001$ as determined by Student's $t$ test.

$(P<0.049)$ (Fig. 2). However, this inhibition was further enhanced, in a dose dependent manner by the inclusion of BB2275 , which maximally reduced $\mathrm{p} 75 \mathrm{sTNF}-\mathrm{R}$ production to 480 $\mathrm{pg} / \mathrm{ml}(P<0.005)$ at a concentration of $5 \mu \mathrm{M}$, indicating that the effect of BB-2275 on p75 sTNF-R shedding was not simply due to inhibition of TNF $\alpha$ production. The most convincing data was derived from studies of the effect of BB-2275 on IL10-induced sTNF-R production. Recently we showed (29) that whilst IL-10 inhibits TNF $\alpha$ production in macrophages, it also augments the production of both p55 and p75 sTNF-Rs in monocyte cultures. This provided an alternative system to test the effects of the MMP inhibitor BB-2275 on STNF-R production in the absence of its effect on $\mathrm{TNF} \alpha$ processing. Monocyte cell cultures in triplicate were incubated with IL-10 $(10 \mathrm{ng} / \mathrm{ml})$ with or without increasing doses of BB-2275 from $0-10 \mu \mathrm{M}$. Small amounts of p75 (400 pg/ml) and p55 (100 pg/ml) sTNF-R were released spontaneously by the monocyte cultures, and this was increased 2-3-fold in the presence of IL-10 (Fig. 3). IL-10-induced shedding was inhibited in a dose dependent manner by BB-2275. The $\mathrm{IC}_{50}$ for BB-2275 in monocytes was $\sim 0.9 \mu \mathrm{M}$ for both p55 and p75 TNF-R and cleavage.

BB-2275 enhances TNF $\alpha$-mediated cytotoxicity in KYM.1D4 rhabdomyosarcoma cells. To determine whether, inhibition of TNF-R release was of biological significance, the sensitivity to human $\mathrm{TNF} \alpha$ of the human KYM 1D4 rhabdomyosarcoma cell line which expresses both p55 and p75 TNF-R (30) was assessed after the cells had been pre-incubated with BB-2275 (0$10 \mu \mathrm{M})$. This pre-incubation with BB-2275 resulted in a dosedependent retention of TNF-R surface expression as determined by ligand binding (Fig. $4 a$ ) and a similar dose-dependent increase in sensitivity to TNF $\alpha$-mediated cytotoxicity (Fig. $4 b$ ). Thus in the control culture $\sim 50 \%$ cytotoxicity was generated by $30 \mathrm{pg} / \mathrm{ml}$ of TNF $\alpha$, whereas in the presence of $10 \mu \mathrm{M} \mathrm{BB}-$ 2275 , a similar level of cytotoxicity was observed with 15 -fold less $(2 \mathrm{pg} / \mathrm{ml}) \mathrm{TNF} \alpha$. 
$\mathbf{a}$

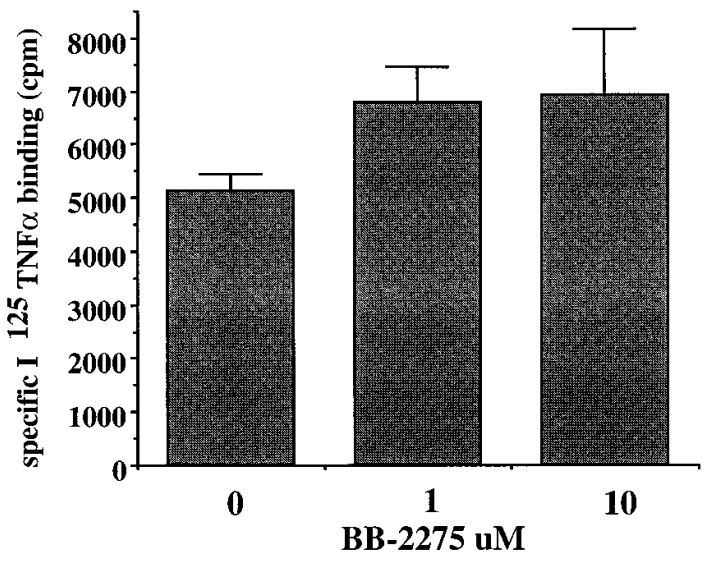

$\mathbf{b}$

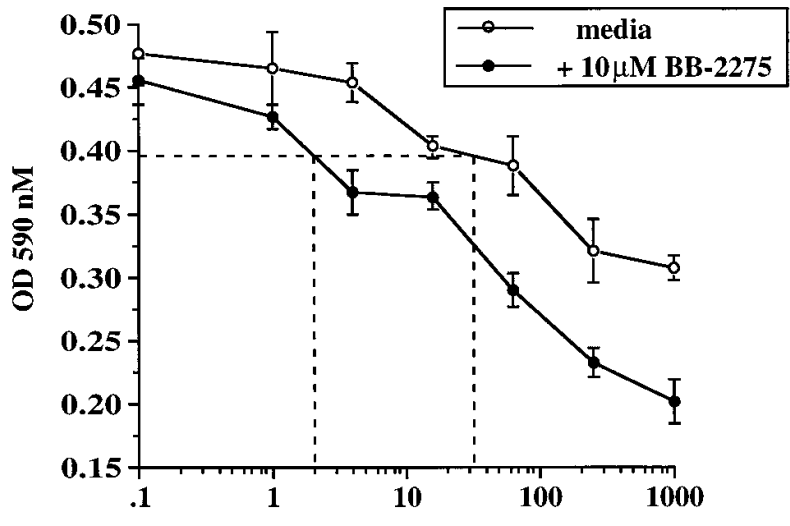

Figure 4. The metalloproteinase inhibitor BB-2275 increases the sensitivity of human KYM 1D4 rhabdomyosarcoma cells to TNF $\alpha$ induced cytotoxicity. KYM 1D4 cells were incubated for $48 \mathrm{~h}$ with BB$2275(0,1$, and $10 \mu \mathrm{M})$ and analyzed for surface TNF-R expression by ligand binding. Results are expressed as mean specific $\mathrm{I}^{125} \mathrm{TNF} \alpha$ binding (cpm) from triplicate cultures \pm SD after subtraction of background binding as described in materials and methods $(a)$. Additionally, TNF $\alpha(0-1000 \mathrm{pg} / \mathrm{ml})$ mediated cytotoxicity was determined in triplicate cultures of KYM 1D4 cells which had been pre incubated with BB-2275, as described in Methods. Results are expressed as OD units, measured at $574 \mathrm{nM}$, where increase in $\mathrm{OD}_{574 \mathrm{nM}}$ value represents cell viability $(b)$.

BB-2275 blocks MMP activity in RA synovial joint cell cultures. BB-2275 is a broad spectrum MMP inhibitor with an in vitro potency (IC50) of $10 \mathrm{nM}$ against MMP-1 and $50 \mathrm{nM}$ against MMP-3 (31). To confirm that MMP activity in the RA synovial cell cultures was inhibited by BB-2275, the activity of these enzymes was determined by the Coumarin assay based on cleavage of a synthetic peptide in vitro. The results (Fig. 5) indicate that BB-2275 inhibited MMP activity in a dose-dependent manner, and at $10 \mu \mathrm{M}$ (the dose used in all (109.7\%) subsequent experiments) all MMP activity was blocked.

$B B-2275$ inhibits TNF and sTNF-R production in $R A$ synovial joint cell cultures. We next examined the effect of BB-2275 in RA synovial membrane cultures, a system in which previously the spontaneous production of a number of cytokines had been shown to be inhibited by the blockade of TNF with a

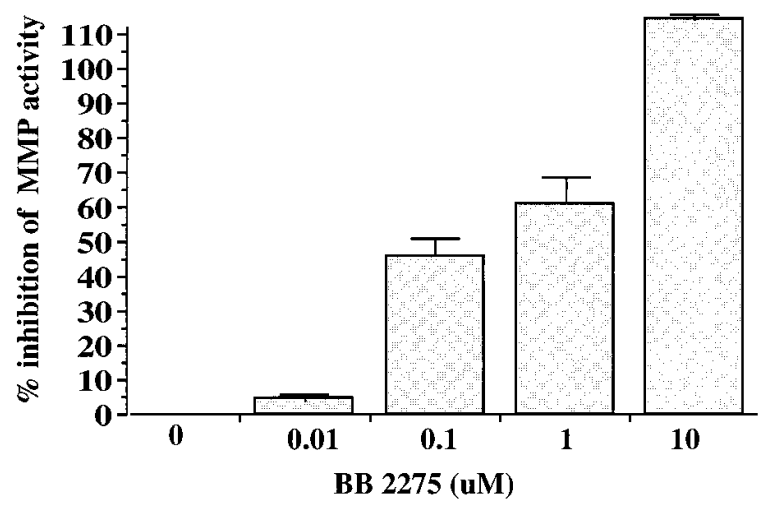

Figure 5. The metalloproteinase inhibitor BB-2275 blocks MMP activity in synovial joint mononuclear cell culture. RA MNC 1613 were set up at $1.5 \times 10^{6} / \mathrm{ml}$ in serum-free media in the presence of BB-2275 $(0-10 \mu \mathrm{M})$ and supernatants harvested after $3 \mathrm{~d}$ in culture. Total MMP activity was determined using the in vitro coumarin assay as described in Methods. Results are expressed as percentage inhibition of MMP activity derived from assay performed in triplicate \pm SD.

neutralizing antibody $(2-4)$. The addition of BB-2275 $(0-25 \mu \mathrm{M})$ to RA synovial membrane cell cultures was found to inhibit TNF $\alpha$ and sTNF-R (p55 and p75) production in a dose-dependent manner, a representative result from synovial membrane culture (SM 1568) is illustrated in Fig. 6. Based on this result, RA synovial membrane cells obtained from ten different patients were cultured with or without $10 \mu \mathrm{M}$ BB-2275, cell supernatants harvested after three days, and cytokine (TNF $\alpha$, IL-1 $\beta$, IL-6, and IL-8) and sTNF-R (p55 and p75) levels measured by ELISA. These results are summarized in Table II and illustrated in Fig. 7. Thus in the presence of BB-2275, the mean level of TNF $\alpha$ was significantly reduced $(P<0.006)$ from $964 \pm 1208 \mathrm{pg} / \mathrm{ml}$ to $24 \pm 36 \mathrm{pg} / \mathrm{ml}$, as were the levels of $\mathrm{p} 75$ sTNF-R $(P<0.004)$ from $1818 \pm 1563$ to $583 \pm 689 \mathrm{pg} / \mathrm{ml}$ and p55 sTNF-R $(P<0.006)$ from $219 \pm 139 \mathrm{pg} / \mathrm{ml}$ to $74 \pm 103 \mathrm{pg} / \mathrm{ml}$. However, despite inhibiting TNF $\alpha$ production, the levels of IL-1 $\beta(1208 \pm 1190 \mathrm{pg} / \mathrm{ml}$ to $1446 \pm 1571 \mathrm{pg} / \mathrm{ml})$, IL-6 (289 \pm 238 to $258 \pm 179 \mathrm{ng} / \mathrm{ml})$ or IL-8 $(258 \pm 141 \mathrm{ng} / \mathrm{ml}$ to $200 \pm 124)$ were not significantly affected with BB-2275.

In contrast to these results we have previously demonstrated that the inclusion of a neutralizing anti-TNF $\alpha$ antibody in these cultures, had the concomitant effect of inhibiting a number of cytokines including IL-1, GM-CSF, IL-6, and IL-8 (2-4). A representative experiment comparing the chimeric anti-TNF antibody, cA2 and BB-2275 in triplicate cultures derived from the RA synovial membranes RA SM1596 and RA SM1597 is summarized in Table III. Thus, after three days in culture, cA2 and BB-2275 had reduced TNF bioactivity to a similar level in RA SM 1596 ( $>90 \%$ inhibition) and RA SM1597 (>97\% inhibition). However, as indicated in Fig. 6, the inclusion of BB-2275 also reduced p55 and p75 sTNF-R production, whereas the levels of these soluble TNF-R levels were relatively unchanged by cA 2 (Table III). Furthermore, as indicated in Fig. 6 and shown in Table III, the inclusion of BB-2275 did not reduce IL-1 $\beta$ levels, and actually increased this cytokine in both RA SM1596 (106\% of control value) and RA SM1597 ( $151 \%$ of control value), whereas the inclusion of $\mathrm{cA} 2$ in these cultures reduced the level of IL-1 $\beta$ to $47 \%$ (RA SM1596) and 77\% (RA SM1597) of control values respec- 


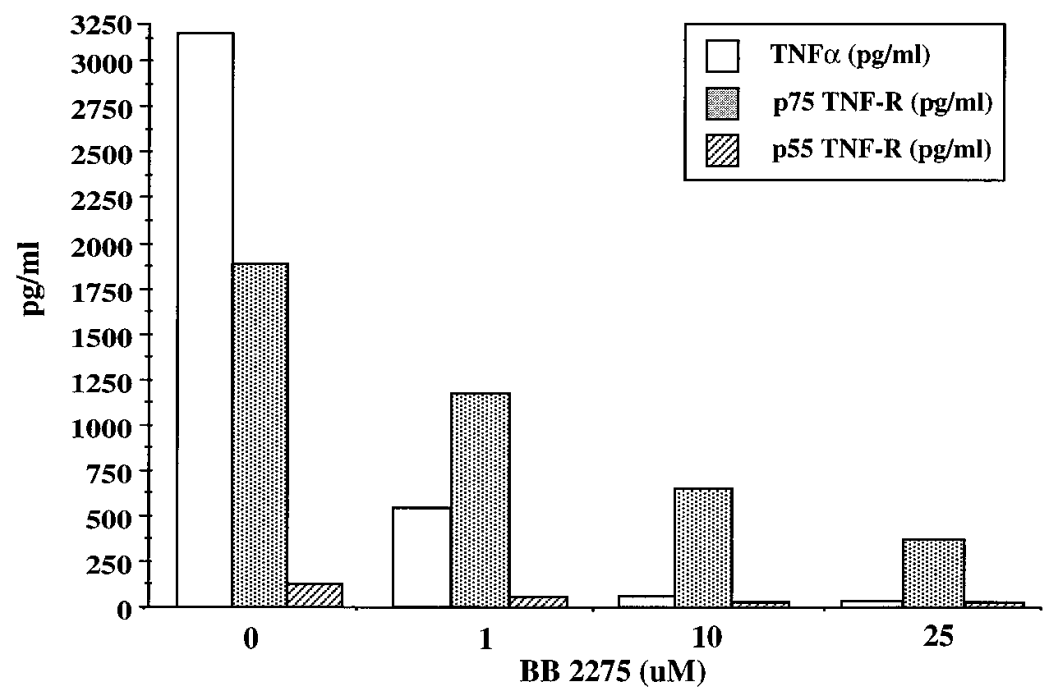

Figure 6. The metalloproteinase inhibitor BB-2275 inhibits TNF $\alpha$ production, $\mathrm{p} 75$ and $\mathrm{p} 55$ sTNF-R release from rheumatoid arthritis synovial joint mononuclear cell cultures. RA MNC (SM1568) were set up at $1.5 \times 10^{6} / \mathrm{ml}$ in the presence of BB-2275 $(0-25 \mu \mathrm{M})$ and supernatants harvested after $3 \mathrm{~d}$ in culture. p75 sTNF-R, p55 sTNF-R and TNF $\alpha$ levels $(\mathrm{pg} / \mathrm{ml})$ were detected by ELISA. tively. Indeed in both RA SM cultures, the level of IL-1 $\beta$ in the BB-2275 treated culture was approximately twice that in the cA2 treated cultures. Interestingly this increase in IL-1 $\beta$ production was still evident in RA SM1597 which was also cultured for five days in which the IL-1 $\beta$ levels in RA SM 1597 were almost two-fold higher $(190 \%)$ than in the control culture, whilst the level of TNF bioactivity was reduced to $<2 \%$ of control values in both the cA2 or BB-2275-treated cultures (Table III).

\section{Discussion}

Over the last few years, several types of cytokine inhibitors have been detected in plasma or urine. The largest group consists of cytokine binding proteins, which are derived from the extracellular domain of their respective cell surface receptors, including interleukin $2(32)$, TNF $(13,14)$, interferon $\gamma(33)$, IL-6 (33), IL-1 (34), IL-4 (35), IL-7 (36), M-CSF (37), and interferon $\alpha / \beta$ (38). Unlike soluble IL-4 and IL-7 receptors which can be generated as alternatively spliced mRNA prod-

Table II. Effect of BB-2275 on Pro-inflammatory Cytokine and Soluble TNF-R Production in Rheumatoid Synovial Membrane Cell Cultures

\begin{tabular}{lccc}
\hline & Control & $\begin{array}{c}\text { BB-2275 } \\
(10 \mu \mathrm{M})\end{array}$ & $P$ value \\
\hline TNF $\alpha(\mathrm{pg} / \mathrm{ml})$ & $904 \pm 1208$ & $24 \pm 36$ & $* P<0.006$ \\
p75 sTNF-R $(\mathrm{pg} / \mathrm{ml})$ & $1818 \pm 1563$ & $583 \pm 689$ & $* P<0.004$ \\
p55 sTNF-R $(\mathrm{pg} / \mathrm{ml})$ & $219 \pm 139$ & $74 \pm 103$ & $* P<0.006$ \\
IL-1 $\beta(\mathrm{pg} / \mathrm{ml})$ & $1208 \pm 1190$ & $1446 \pm 1571$ & $\mathrm{~ns}$ \\
IL-6 $(\mathrm{ng} / \mathrm{ml})$ & $289 \pm 238$ & $258 \pm 179$ & $\mathrm{~ns}$ \\
IL-8 $(\mathrm{ng} / \mathrm{ml})$ & $258 \pm 141$ & $200 \pm 124$ & $\mathrm{~ns}$
\end{tabular}

Synovial membrane cells were isolated from synovial tissue obtained from RA patients $(n=10)$ and placed in culture with or without BB-2275 $(10 \mu \mathrm{M})$. Supernatants were harvested after $3 \mathrm{~d}$ in culture and cytokine and sTNF-R levels determined by ELISA. Results are expressed as mean $\pm \mathrm{SD}$ of 10 cultures and *analyzed using the Willcoxon nonparametric test. ucts, the majority of these soluble cytokine receptors are generated by proteolytic cleavage of the full length membrane receptor.

The process of shedding cell receptors is important, as it upregulates soluble receptor production and also provides a mechanism for desensitizing cells to the biological effects of ligand. This is achieved by reducing the concentration of surface receptors, thus modulating the signaling and also by inhibiting the ligand competitively. The mechanism(s) resulting in shedding of cell surface pro-inflammatory cytokines receptors, such as TNF-R, is of great interest, as it reduces the pathogenic effects of these cytokines (11). TNF-R release has been most extensively studied in activated neutrophils (PMN) (39). Elastase contained within the azurophil granules of PMNs induces $\mathrm{p} 75$ but not p55 TNF-R shedding. However, production of both p75 (42 kD) and p55 (28 kD) TNF-R fragments in $\mathrm{PMNs}$ in response to the chemotactic peptide f-met-leu-phe was not affected by inhibitors of elastase. It is probable therefore that other enzymes are involved in the cleavage of TNF-R in PMNs. Hwang et al. (40) reported that the PMA induced shedding in myeloid THP-1 cells was inhibited by a range of different serine protease inhibitors. We have made similar observations in peripheral blood monocyte cultures using the serine protease inhibitor 3,4 dichloroisocoumarin (DCI), however in our experiments the $\mathrm{IC}_{50}$ for DCI was high $(\sim 25 \mu \mathrm{M})$, and at this concentration the compound was toxic for the cells.

The results presented in this manuscript describe the novel finding that a broad spectrum synthetic inhibitor of matrix metalloproteinase activity (BB-2275) (31) is also a potent inhibitor of both p75 and p55 TNF receptor shedding. This was observed in a wide range of different cell types including $\mathrm{HeLa}$ cells expressing only p55, JiJoye and T cells expressing p75, or U937 and peripheral blood monocytes, expressing both receptors. Inhibition of receptor shedding was demonstrated by a reduction of the release of sTNF-R into the culture supernatant, and a concomitant increase in TNF-R on the cell surface. Although tissues at sites of inflammation such as rheumatoid synovium tissue produce high levels of MMPs, it was unexpected that a synthetic inhibitor of MMPs would inhibit cleavage of both TNF receptors, as cleavage sites on the MMP substrates such as collagen or elastin are not obviously shared with the p55 or p75 TNF-R. Indeed, the sequence homology be- 


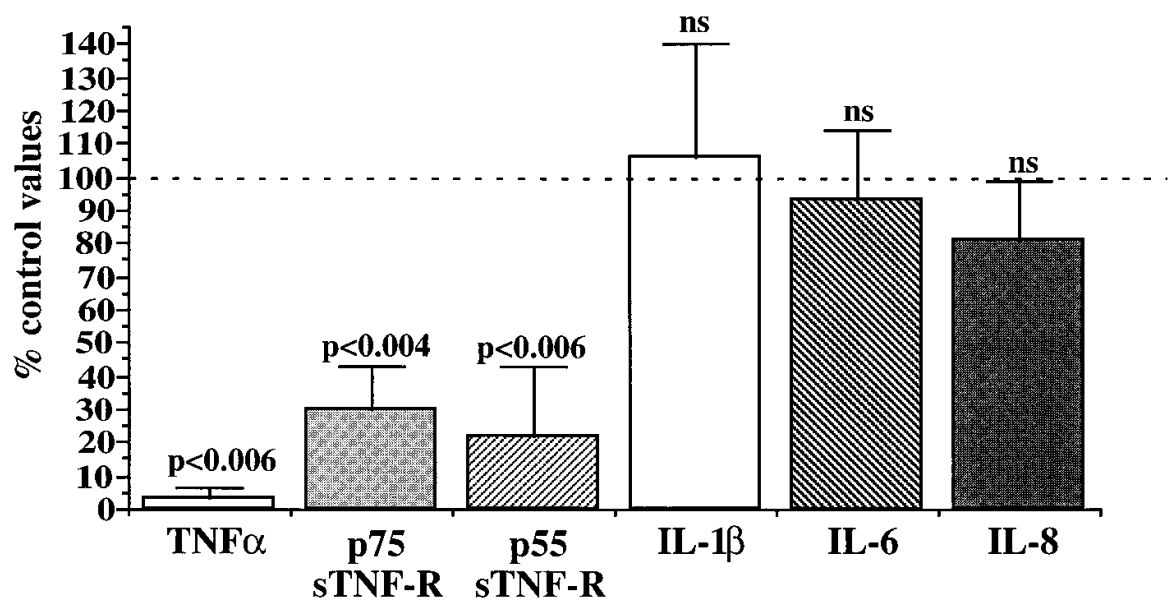

Figure 7. Effect of the metalloproteinase inhibitor BB-2275 on pro-inflammatory cytokine production in rheumatoid arthritis synovial joint mononuclear cell cultures. RA MNC from RA synovial joints $(n=10)$ were incubated in vitro with $10 \mu \mathrm{M}$ BB2275. After $3 \mathrm{~d}$ in culture cell supernatants were harvested and TNF $\alpha, \mathrm{p} 75$ sTNF-R, p55 sTNF-R, IL-1 $\beta$, IL-6, and IL-8 levels determined by ELISA. Results are expressed as percentage of control $(100 \%)$ values \pm SD from the raw data summarized in Table II and statistical analysis performed by the willcoxon rank test as the control data was not normally distributed.

tween the p55 and the p75 TNF-R is small ( $\sim 25 \%)$, and the putative enzyme cleavage site identified on the p55 TNF-R by site directed mutagenesis (Asn/Val) is not present on the p75 TNF-R (15). However, the number and variety of published MMP substrates and cleavage sites is increasing. For example, it has been reported that hydroxamate based inhibitors of MMPs could also inhibit processing of 26-kD TNFo $(18,24$, 25). Although several of the known MMPs can authentically process a recombinant $\mathrm{TNF} \alpha$ substrate (18), it is not clear at

Table III. Comparison of BB-2275 with Chimeric Anti-TNF Antibody on Cytokine and Soluble TNF-R Production in RA Synovial Cultures

\begin{tabular}{lcccc}
\hline & $\begin{array}{c}\text { TNF } \\
(\mathrm{pg} / \mathrm{ml})\end{array}$ & $\begin{array}{c}\mathrm{p} 75 \mathrm{sTNF}-\mathrm{R} \\
(\mathrm{pg} / \mathrm{ml})\end{array}$ & $\begin{array}{c}\mathrm{p} 55 \mathrm{sTNF}-\mathrm{R} \\
(\mathrm{pg} / \mathrm{ml})\end{array}$ & $\begin{array}{c}\mathrm{IL}-1 \beta \\
(\mathrm{pg} / \mathrm{ml})\end{array}$ \\
\hline SM 1596 day 3 & & & & \\
Control & $137 \pm 44$ & $508 \pm 3$ & nd & $1608 \pm 136$ \\
BB-2275 $(10 \mu \mathrm{M})$ & $13 \pm 3$ & $102 \pm 14$ & nd & $1708 \pm 124$ \\
$\%$ Control value & $(9.5 \%)$ & $(20 \%)$ & & $(106 \%)$ \\
cA2 $(2.5 \mu \mathrm{g} / \mathrm{ml})$ & $8.3 \pm 1.9$ & $508 \pm 2.8$ & nd & $762 \pm 68$ \\
$\%$ Control value & $(6 \%)$ & $(100 \%)$ & & $(47 \%)$ \\
SM 1597 day 3 & & & & \\
Control & $458 \pm 73$ & $532 \pm 2$ & $130 \pm 11$ & $2341 \pm 110$ \\
BB-2275 $(10 \mu \mathrm{M})$ & $15 \pm 1.3$ & $139 \pm 6$ & $\mathrm{nd}$ & $3519 \pm 324$ \\
$\%$ Control value & $(3.3 \%)$ & $(26 \%)$ & & $(151 \%)$ \\
cA2 $(2.5 \mu \mathrm{g} / \mathrm{ml})$ & $10 \pm 0.3$ & $486 \pm 15$ & $146 \pm 56$ & $1793 \pm 256$ \\
$\%$ Control value & $(2.2 \%)$ & $(86 \%)$ & $(112 \%)$ & $(77 \%)$ \\
SM 1597 day 5 & & & & \\
Control & $215 \pm 58$ & $507 \pm 18$ & $112 \pm 33$ & $2069 \pm 5$ \\
BB-2275 $(10 \mu \mathrm{M})$ & $3.9 \pm 2.6$ & $161 \pm 26$ & $<30$ & $3934 \pm 1291$ \\
$\%$ Control value & $(1.8 \%)$ & $(32 \%)$ & & $(190 \%)$ \\
cA2 $(2.5 \mu \mathrm{g} / \mathrm{ml})$ & $3.5 \pm 0.05$ & $585 \pm 21$ & $135 \pm 36$ & $1675 \pm 194$ \\
& $(1.6 \%)$ & $(115 \%)$ & $(120 \%)$ & $(80 \%)$ \\
& & & &
\end{tabular}

Synovial membrane cells were isolated from synovial tissue obtained from RA patient SM 1596 and SM 1597 were placed in culture in triplicate with or without BB-2275 $(10 \mu \mathrm{M})$ or the neutralizing monoclonal anti-TNF antibody cA2 $(2.5 \mu \mathrm{g} / \mathrm{ml})$. Supernatants were harvested after 3 or $5 \mathrm{~d}$ in culture. TNF levels were determined by the TNF bioassay as cA2 interferes with the ELISA, and soluble TNF-R levels and IL-1 $\beta$ production measured by ELISA. Results are expressed as mean \pm SD of three triplicate cultures. $n d$, not detected. this stage if the TNF convertase is a classical MMP, or whether it is an unique enzyme.

As synthetic MMP inhibitors such as BB-2275 block both $\mathrm{TNF} \alpha(18)$ and TNF-R secretion, and TNF $\alpha$ itself can induce TNF-R shedding, it was necessary to determine if the effect on TNF-R shedding by BB-2275 was indirect, due to its inhibitory activity on TNF $\alpha$ processing. This was demonstrated in three ways. First, BB-2275 inhibited p55 sTNF-R production in a cell line (HeLa) which does not secrete TNF $\alpha$. Second, p75 sTNF-R production in LPS-stimulated monocyte was reduced by $90 \%$ with BB-2275 $(P<0.005)$ compared with $25 \%$ by blocking $\mathrm{TNF} \alpha$ activity with a neutralizing monoclonal anti-TNF $\alpha$ antibody $(P<0.049)$. Third, BB-2275 inhibited p55 and p75 sTNF-R production in monocyte cultures, in which the production of TNF $\alpha$ (41) but not sTNF-R (29) had been blocked by the inclusion of IL-10.

The association between the TNF convertase and the enzymes(s) involved in TNF receptor cleavage as described in this report has yet to be established, although the $\mathrm{IC}_{50}$ of BB-2275 in LPS-stimulated monocytes for both TNF $(0.5 \mu \mathrm{M})$ and p75 sTNF-R production $(0.8 \mu \mathrm{M})$ is similar (data not shown). Furthermore, as TNF-negative cells process precursor TNF to its mature form if transfected with the full length TNF cDNA (G.M. McGeehan and J.M. Clements, personal communications), and the inhibition of TNF-R shedding by BB-2275 occurs in many different cell types, this indicates that the enzyme(s) involved are widely distributed. In addition to its wide cellular distribution, this enzyme appears to be induced and/or activated by a number of different stimuli including IL-10. This observation is of particular interest as IL-10 upregulates sTNF-R production (29), whilst inhibiting $\mathrm{TNF} \alpha$ production at the transcriptional level.

From the studies described in this report it is not possible to identify the point in the enzyme cascade leading to TNF-R shedding where BB-2275 exerts its inhibitory effect. MMPs are produced as inactive zymogens which are activated by enzymes such as plasmin or other MMPs, or by autocatalysis (42). Thus, inhibition of enzymatic activity at any point in this cascade, and not necessarily at the most distal point would subsequently result in inhibition of shedding. The generation of enzyme-specific rather than class-specific inhibitors, or the cloning and expression of a novel TNF convertase will shed light on the intriguing possibility that the enzyme(s) involved in TNF-R cleavage and the TNF convertase are related, or 
perhaps even identical. Furthermore, as MMPs have also been implicated recently in cleavage of other surface receptors including the low-affinity nerve growth factor and L-selectin (43), the availability of more specific inhibitors of MMP activity will enable the extent to which such cleavage events are associated to be determined.

From the results described in this paper it suggests that hydroxamic acid inhibitors of MMP activity inhibit both TNF receptor shedding, and the conversion of membrane TNF $\alpha$ to its secreted counterpart. One possible consequence of these effects is that more surface TNF-R will be expressed on the cells with an accumulation of membrane TNFo (24). During the preparation of this manuscript, it was reported by Crowe and colleagues (44) that a metalloproteinase inhibitor blocked shedding of the $\mathrm{p} 75 \mathrm{TNF}-\mathrm{R}$ and TNF processing in activated T lymphocytes. They speculated that such MMP inhibitors may offer protection from TNF at two levels both by preventing TNF release, and secondly by blocking accumulation of shed TNF-R, which has been shown to stabilize TNF activity in vitro (45). In contrast we have demonstrated that sTNF-R in synovial fluid or in rheumatoid synovial cell supernatant blocks $\mathrm{TNF} \alpha$ bioactivity $(11,12)$. We speculated therefore, that the beneficial protective effects of such MMP inhibitors would depend on the degree to which the membrane (nonprocessed) TNF $\alpha$ could still signal to surface TNF-R. We demonstrated first, that the inhibition of TNF-R shedding and the consequent accumulation of surface TNF-R rendered KYM.1D4 cells more sensitive to the cytotoxic signaling actions of soluble TNF $\alpha$. Thus the degree of surface TNF-R retention induced by BB2275 was biologically meaningful. Secondly, we addressed the consequences of using an MMP inhibitor in RA synovial cell cultures, a useful disease model system in vitro (2). In these cells membrane TNF $\alpha$ is expressed, and the production of many pro-inflammatory cytokines including $\mathrm{TNF} \alpha$, and many soluble cytokine receptors including sTNF-Rs occurs without exogenous stimulation. The addition of BB-2275 to these inflammatory cell cultures totally inhibited MMP activity and also inhibited $\mathrm{TNF} \alpha$ secretion very efficiently, and the production of p55 and p75 sTNF-R. We speculated that if inhibition of TNF $\alpha$ processing and TNF-R shedding in these cultures resulted in accumulation of membrane (biologically active) TNF $\alpha$ and surface TNF-R, then 'down-stream' effects of $\mathrm{TNF} \alpha$, in particular induction of other pro-inflammatory cytokines such as IL-1, IL-6 or IL-8 which we have shown to be $\mathrm{TNF} \alpha$-dependent $(2,4)$ would not be blocked. This was found to be the case, as IL-1, IL-6, and IL-8 levels were unchanged with BB-2275, whereas as previously shown (2-4) neutralization of TNF $\alpha$ with an antibody that blocks both membrane and secreted TNF $\alpha$, was found to inhibit the production of IL-1, GM-CSF, IL-6, and IL-8. The TNF $\alpha$ dependence of cytokines in vivo in RA has also been confirmed in recent anti-TNF $\alpha$ clinical trials in RA patients (46), in which we observed that serum IL-6 levels were reduced. One conclusion to be drawn from these findings is that although hydroxamate compounds will effectively block TNF $\alpha$ secretion, this "beneficial" effect may be negated by the upregulation of TNF $\alpha$ signaling due to the hydroxamate induced accumulation of membrane-anchored $\mathrm{TNF} \alpha$, and the concomitant retention of cell surface TNF-R, accompanied by a reduction in STNF-R production. However, it should be noted that hydroxamic acid MMP inhibitors are effective in models of arthritis $(47,48)$, but this is most likely due to their inhibitory effects on the degradative MMP en- zymes for which they were optimized. Indeed in the second study in adjuvant arthritis in rats (48) the authors were careful to point out that the compound they used was not a potent TNF convertase inhibitor and that the steady state plasma levels would not be sufficient to inhibit TNF production. It has yet to be demonstrated that greater efficacy can be achieved with a compound which blocks both MMP and TNF convertase activity in these models of arthritis. Alternatively, it might be predicted that better efficacy would be achieved by using a neutralizing anti $\mathrm{TNF} \alpha$ antibody therapy in conjunction with a hydroxamate compound. However, in light of the results presented in this paper, there is a need to identify MMP inhibitors which specifically inhibit TNF $\alpha$ convertase, without inhibiting TNF-R shedding. It will be of great interest to compare compounds with selectivities for different MMPs and which can discriminate between the TNF convertase and the TNF-R protease for their efficacy in models of arthritis.

\section{Acknowledgments}

We would also like to thank Dr. Karen Miller and George Ward (Neures) for performing the coumarin assay to detect MMP activity in the RA synovial cell culture supernatants, and the British Biotech metalloproteinase team for the production of the MMP-inhibitor compound used in this paper.

This work was supported by the Arthritis and Rheumatism Council and Medical Research Council.

\section{References}

1. Brennan, F.M., R.N. Maini, and M. Feldmann. 1992. TNF $\alpha$ - a pivotal role in rheumatoid arthritis? Br. J. Rheumatol. 31:293-298.

2. Brennan, F.M., D. Chantry, A. Jackson, R. Maini, and M. Feldmann. 1989. Inhibitory effect of TNF $\alpha$ antibodies on synovial cell interleukin-1 production in rheumatoid arthritis. Lancet. 2:244-247.

3. Haworth, C., F.M. Brennan, D. Chantry, M. Turner, R.N. Maini, and M. Feldmann. 1991. Expression of granulocyte-macrophage colony-stimulating factor in rheumatoid arthritis: regulation by tumor necrosis factor- $\alpha$. Eur. J. Immunol. 21:2575-2579.

4. Butler, D., R.N. Maini, M. Feldmann, and F.M. Brennan. 1995. Blockade of TNF $\alpha$ with chimeric anti TNFa monoclonal antibody, cA2 reduces (IL-6 and IL-8) release in RA NMC cultures: A comparison with IL-1ra. Eur. Cytokine Netw. 6:225-230.

5. Gray, P.W., K. Barrett, D. Chantry, M. Turner, and M. Feldmann. 1990. Cloning of human tumor necrosis factor (TNF) receptor cDNA and expression of recombinant soluble TNF-binding protein. Proc. Natl. Acad. Sci. USA. 87: $7380-7384$.

6. Smith, C.A., T. Davis, D. Anderson, L. Solam, M.P. Beckmann, R. Jerzy, S.K. Dower, D. Cosman, and R.G. Goodwin. 1990. A receptor for tumor necrosis factor defines an unusual family of cellular and viral proteins. Science (Wash. DC). 248:1019-1023.

7. Brennan, F.M., D.L. Gibbons, T. Mitchell, A.P. Cope, R.N. Maini, and M. Feldmann. 1992. Enhanced expression of tumor necrosis factor receptor mRNA and protein in mononuclear cells isolated from rheumatoid arthritis synovial joints. Eur. J. Immunol. 22:1907-1912.

8. Chu, C.Q., M. Field, M. Feldmann, and R.N. Maini. 1991. Localization of tumor necrosis factor $\alpha$ in synovial tissues and at the cartilage-pannus junction in patients with rheumatoid arthritis. Arthritis Rheum. 34:1125-1132.

9. Deleuran, B.W., C.Q. Chu, M. Field, F.M. Brennan, T. Mitchell, M. Feldmann, and R.N. Maini. 1992. Localization of tumor necrosis factor receptors in the synovial tissue and cartilage-pannus junction in patients with rheumatoid arthritis. Implications for local actions of tumor necrosis factor $\alpha$. Arthritis Rheum. 35:1170-1178.

10. Katsikis, P., C.Q. Chu, F.M. Brennan, R.N. Maini, and M. Feldmann. 1994. Immunoregulatory role of interleukin 10 (IL-10) in Rheumatoid Arthritis. J. Exp. Med. 179:1517-1527.

11. Cope, A.P., D. Aderka, M. Doherty, H. Engelmann, D. Gibbons, A.C. Jones, F. M. Brennan, R.N. Maini, D. Wallach, and M. Feldmann. 1992. Increased levels of soluble tumor necrosis factor receptors in the sera and synovial fluid of patients with rheumatic diseases. Arthritis Rheum. 35:1160-1169.

12. Brennan, F.M., D. Gibbons, A. Cope, P. Katsikis, R.N. Maini, and M. Feldmann. 1995. TNF inhibitors are produced spontaneously by rheumatoid and osteoarthritic synovial joint cell cultures: evidence of feedback control of 
TNF action. Scand. J. Immunol. 42:158-165.

13. Seckinger, P., S. Isaaz, and J.M. Dayer. 1989. Purification and biologic characterization of a specific tumor necrosis factor alpha inhibitor. J. Biol. Chem. 264:11966-11973.

14. Engelmann, H., D. Aderka, M. Rubinstein, D. Rotman, and D. Wallach. 1989. A tumor necrosis factor-binding protein purified to homogeneity from human urine protects cells from tumor necrosis factor toxicity. J. Biol. Chem. 264:11974-11980.

15. Gullberg, U., M. Lantz, L. Lindvall, I. Olsson, and A. Himmler. 1992. Involvement of an Asn/Val cleavage site in the production of a soluble form of a human tumor necrosis factor (TNF) receptor. Site-directed mutagenesis of a putative cleavage site in the p55 TNF receptor chain. Eur. J. Cell Biol. 58:307312

16. Porteu, F., M. Brockhaus, D. Wallach, H. Engelmann, and C.F. Nathan. 1991. Human neutrophil elastase releases a ligand-binding fragment from the 75-kDa tumor necrosis factor (TNF) receptor. Comparison with the proteolytic activity responsible for shedding of TNF receptors from stimulated neutrophils. J. Biol. Chem. 266:18846-18853.

17. Brinckerhoff, C.E. 1991. Joint destruction in arthritis: metalloproteinases in the spotlight. Arthritis Rheum. 34:1073-1975.

18. Gearing, A.J.H., P. Beckett, M. Christodoulou, M. Churchill, J. Clements, A.H. Davidson, A.H. Drummond, W.A. Galloway, R. Gilbert, J.L. Gordon et al. 1994. Processing of tumour necrosis factor- $\alpha$ precursor by metalloproteinases. Nature (Lond.). 370:555-557.

19. Cope, A.P., D.L. Gibbons, D. Aderka, B.M. Foxwell, D. Wallach, R.N. Maini, M. Feldmann, and F.M. Brennan. 1993. Differential regulation of tumour necrosis factor receptors (TNF-R) by IL-4; upregulation of P55 and P75 TNF-R on synovial joint mononuclear cells. Cytokine. 5:205-212.

20. Leeuwenberg, J.F.M., G.M.M.A. Jeunhomme, and W.A. Buurman. 1994. Slow release of soluble TNF receptors by monocytes in vitro. J. Immunol. 154:4036-4043

21. Engelberts, I., A. Moller, G.J.M. Schoen, C.J. van der Linden, and W.A. Buurman. 1991. Evaluation of human TNF in plasma by ELISA. Lymphokine Cytokine Res. 10:60-76.

22. Meager, A. 1991. A cytotoxic assay for tumor necrosis factor using a human rhabdomyosarcoma cell line. J. Immunol. Methods. 144:141-143.

23. Knight, C.G., F. Willenbrock, and G. Murphy. 1992. A novel coumarinlabelled peptide for sensitive continuous assays of the matrix metalloproteinases. FEBS Lett. 296(3):263-266.

24. McGeehan, G.M., J.D. Becherer, J. Bast R.C., C.M. Boyer, B. Champion, K. M. Connolly, J.G. Conway, P. Furdon, S. Karp, S. Kidao et al. 1994. Regulation of tumour necrosis factor- $\alpha$ processing by a metalloproteinase inhibitor. Nature (Lond.). 370:558-561.

25. Mohler, K., P.R. Sleath, J.N. Fitzner, D.P. Cerretti, M. Alderson, S.S. Kerwar, D.S. Torrance, C. Otten-Evans, T. Greenstreet, K. Weerawarna et al. 1994. Protection against a lethal dose of endotoxin by an inhibitor of tumour necrosis factor processing. Nature (Lond.). 370:218-220.

26. Imamura, K., D. Spriggs, and D. Kufe. 1987. Expression of tumour necrosis factor receptors on human monocytes and internalization of receptor bound ligand. J. Immunol. 139:2989-2992.

27. Lantz, M., S. Malik, M.L. Slevin, and I. Olsson. 1990. Infusion of tumor necrosis factor (TNF) causes an increase in circulating TNF-binding protein in humans. Cytokine. 2:402-406.

28. Kruys, V., K. Kemmer, A. Shakov, V. Jongeneel, and B. Beutler. 1992. Constitutive activity of the tumor necrosis factor promoter is canceled by the $3^{\prime}$ untranslated region in nonmacrophage cell lines; a trans-dominant factor overcomes this suppressive effect. Proc. Natl. Acad. Sci. USA. 89:673-677.

29. Joyce, D.A., D. Gibbons, P. Green, M. Feldmann, and F.M. Brennan. 1994. Two inhibitors of pro-inflammatory cytokine release, IL-10 and IL-4, have contrasting effects on release of soluble p75 TNF receptor by cultured monocytes. Eur. J. Immunol. 24:2699-2705.

30. Butler, D., B. Scallon, A. Meager, M. Kissonerghis, A. Corcoran, Y. Chernajovsky, M. Feldmann, J. Ghrayeb, and F. Brennan. 1994. TNF receptor fusion proteins are effective inhibitors of TNF-mediated cytotoxicity on human KYM-1D4 rhabdomyosarcoma cells. Cytokine. 6:616-623.

31. Chandler, S., R. Coates, A. Gearing, J. Lury, G. Wells, and E. Bone. 1995. Matrix metalloproteinases degrade myelin basic protein. Neurosci. Lett. 201:223-226.

32. Rubin, L.A., C.C. Kurman, M.E. Fritz, W.E. Biddison, B. Boutin, R Yarchoan, and D.L. Nelson. 1985. Soluble interleukin 2 receptors are released from activated human lymphoid cells in vitro. J. Immunol. 135:3172-3177.

33. Novick, D., H. Engelmann, D. Wallach, and M. Rubinstein. 1989. Soluble cytokine receptors are present in normal human urine. J. Exp. Med. 170: 1409-1414.

34. Symons, J.A., J.A. Eastgate, and G.W. Duff. 1991. Purification and characterization of a novel soluble receptor for interleukin-1. J. Exp. Med. 174: 1251-1254.

35. Mosley, B., M.P. Beckmann, C.J. March, R.L. Idzerda, S.D. Gimpel, T. VandenBos, D. Friend, A. Alpert, D. Anderson, J. Jackson et al. 1989. The murine interleukin-4 receptor: molecular cloning and characterization of secreted and membrane bound forms. Cell. 59:335-348.

36. Goodwin, R.G., D. Friend, S.F. Ziegler, R. Jerzy, B.A. Falk, S. Gimpel, D. Cosman, S.K. Dower, C.J. March, A.E. Namen, and L.S. Park. 1990. Cloning of the human and murine interleukin-7 receptors: demonstration of a soluble form and homology to a new receptor superfamily. Cell. 60:941-951.

37. Downing, J.R., M.F. Roussel, and C.J. Sherr. 1989. Ligand and protein kinase $\mathrm{C}$ downmodulate the colony-stimulating factor 1 receptor by independent mechanisms. Mol. Cell. Biol. 9:2890-2896.

38. Novick, D., B. Cohen, and M. Rubinstein. 1994. The human interferon $\alpha / \beta$ receptor: characterization and molecular cloning. Cell. 77:391-400.

39. Porteu, F., and C. Nathan. 1990. Shedding of tumor necrosis factor receptors by activated human neutrophils. J. Exp. Med. 172:599-607.

40. Hwang, C., M. Gatanaga, G.A. Granger, and T. Gatanaga. 1993. Mechanism of release of soluble forems of tumor necrosis factor/lymphotoxin receptors by phorbol myristate acetate-stimulated human THP-1 cells in vitro. J. Immunol. 151:5631-5638.

41. de Waal-Malefyt, R., J. Abrams, B. Bennett, C.G. Figdor, and J.E. Vries de. 1991. Interleukin (IL-10) inhibits cytokine synthesis by human monocytes: an autoregulatory role of IL-10 produced by monocytes. J. Exp. Med. 174:12091220

42. Stetler-Stevensom, W., H.C. Krutzch, I.M.K. Wacher, M.K. Marguiles, and L. A. Liotta. 1989. The activation of the human type IV collagenase proenzyme. J. Biol. Chem. 164:1353-1356.

43. DiStefano, P.S., D.M. Chelsea, C.M. Schick, and J.F. McKelvy. 1993. Involvement of a metalloprotease in low-affinity nerve growth factor receptor truncation: inhibition of truncation in vitro and in vivo. J. Neurosci. 13:24052414.

44. Crowe, P.D., B.N. Walter, K.M. Mohler, C. Otten-Evans, R.A. Black, and C.F. Ware. 1994. A metalloprotease inhibitor blocks shedding of the $80 \mathrm{kD}$ TNF receptor and TNF processing in T lymphocytes. J. Exp. Med. 181:12051210 .

45. Aderka, D., H. Engelmann, Y. Maor, C. Brakebusch, and D. Wallach. 1992. Stabilization of the bioactivity of tumour necrosis factor by its soluble receptors. J. Exp. Med. 175:323-329.

46. Elliott, M.J., R.N. Maini, M. Feldmann, A. Long-Fox, P. Charles, H. Bijl, and J.N. Woody. 1994. Repeated therapy with monoclonal antibody to tumour necrosis factor $\alpha$ (cA2) in patients with rheumatoid arthritis. Lancet. 344: $1125-1127$.

47. DiMartino, M., W. High, W.A. Galloway, and M.J. Crimmin. 1994. Preclinical antiarthritic activity of MMP inhibitors. Ann. NY Acad. Sci. 732:411413.

48. Conway, J.C., J.A. Wakefield, R.H. Brown, B.E. Marron, L. Sekut, A Stimpson, A.B. McElroy, J.A. Menius, J.J. Jeffreys, R.L. Clark, G.M. McGeehan, and K.M. Connolly. 1995. Inhibition of cartilage and bone destruction in adjuvant arthritis in the rat by a matrix metalloproteinase inhibitor. $J$. Exp. Med. 182:449-458. 